\title{
Effect of K-N-Humates on Dry Matter Production and Nutrient Use Efficiency of Maize in Sarawak, Malaysia
}

\author{
Auldry Chaddy Petrus ${ }^{1}$, Osumanu Haruna Ahmed ${ }^{1 *}$, Ab Majid Nik Muhamad ${ }^{2}$, \\ Hassan Mohammad Nasir ${ }^{3}$, and Make Jiwan ${ }^{1}$ \\ ${ }^{1}$ Department of Crop Science, Faculty of Agriculture and Food Sciences, Universiti \\ Putra Malaysia Bintulu Sarawak Campus, Bintulu, Sarawak, Malaysia; ${ }^{2}$ Department \\ of Forest Management, Faculty of Forestry, Universiti Putra Malaysia, Serdang, \\ Selangor, Malaysia; ${ }^{3}$ Department of Animal Science and Fishery, Faculty of \\ Agriculture and Food Sciences, Universiti Putra Malaysia Bintulu Sarawak Campus, \\ Bintulu, Sarawak, Malaysia \\ E-mail: osman60@hotmail.com
}

Received February 25, 2010; Revised April 27, 2010; Accepted May 24, 2010; Published July 6, 2010

Agricultural waste, such as sago waste (SW), is one of the sources of pollution to streams and rivers in Sarawak, particularly those situated near sago processing plants. In addition, unbalanced and excessive use of chemical fertilizers can cause soil and water pollution. Humic substances can be used as organic fertilizers, which reduce pollution. The objectives of this study were to produce $\mathrm{K}$ - and ammonium-based organic fertilizer from composted SW and to determine the efficiency of the organic-based fertilizer produced. Humic substances were isolated using standard procedures. Liquid fertilizers were formulated except for T2 (NPK fertilizer), which was in solid form. There were six treatments with three replications. Organic fertilizers were applied to soil in pots on the 10th day after sowing (DAS), but on the 28th DAS, only plants of T2 were fertilized. The plant samples were harvested on the 57th DAS during the tassel stage. The dry matter of plant parts (leaves, stems, and roots) were determined and analyzed for $\mathbf{N}, \mathbf{P}$, and $\mathrm{K}$ using standard procedures. Soil of every treatment was also analyzed for exchangeable $\mathrm{K}, \mathrm{Ca}$, $\mathrm{Mg}$, and $\mathrm{Na}$, organic matter, organic carbon, available $\mathrm{P}, \mathrm{pH}$, total $\mathrm{N}$, $P$, nitrate and ammonium contents using standard procedures. Treatments with humin (T5 and T6) showed remarkable results on dry matter production; N, P, and K contents; their uptake; as well as their use efficiency by maize. The inclusion of humin might have loosened the soil and increased the soil porosity, hence the better growth of the plants. Humin plus inorganic fertilizer provided additional nutrients for the plants. The addition of inorganic fertilizer into compost is a combination of quick and slow release sources, which supplies $\mathbf{N}$ throughout the crop growth period. Common fertilization by surface application of T2 without any additives (acidic and high CEC materials) causes $\mathbf{N}$ and $\mathrm{K}$ to be easily lost. High $\mathrm{Ca}$ in the soil may have reacted with phosphate from fertilizer to form $\mathrm{Ca}$ phosphate, an insoluble compound of phosphate that is generally not available to plants, especially roots. Mixing soil with humin produced from composted SW before application of fertilizers (T5 and T6) significantly increased maize dry matter production and nutrient use efficiency. Additionally, this practice does not only improve $N$, $P$, and $K$ 


\section{use efficiency, but it also helps to reduce the use of $\mathrm{N}-$, $\mathrm{P}-$, and $\mathrm{K}$-based fertilizers by $50 \%$.}

KEYWORDS: sago waste, humic substances, humin, maize, nitrogen, potassium

\section{INTRODUCTION}

The main product of the sago palm (Metroxylon sagu) is starch. The state of Sarawak, Malaysia at present is the principal producer of sago, exporting about 25,000 to 40,000 tonnes of sago starch annually[1]. Sago waste (SW), which is copious fibrous residue, is disposed after starch extraction from the sago trunk. For every $100 \mathrm{~kg}$ of sago starch in pith (70-90 kg can be extracted), there is $10 \mathrm{~kg}$ of waste[2]. In addition, SW is likely to be discarded into rivers because most of the factories are built near riversides. This practice may cause water pollution. In addition, inefficient starch extraction will contribute to large amounts of waste[3]. This quantity may be greater if the extraction efficiency is low as sugars, proteins[2], and starches can create high BOD and COD levels in the river[4]. Some researchers have used SW as a substrate for cultivation of edible mushrooms[5], animal feed, production of enzymes[6] and absorbents[7], to reduce this waste.

From an environmental standpoint, SW can be used for agricultural purposes where it can be composted to obtain organic fertilizer. In addition, both of these outputs may reduce the environmental pollution caused by agricultural waste (e.g., SW) and chemical fertilizers. Composting can be considered as the humification technology[8] that occurs when a large part of original organic matter is mineralized and residual organic matter is transformed into new organic materials called humic substances[9]. Humic substances are known as one of the greatest carbon reservoirs on earth and they are used for agricultural, industrial, environmental, and biomedical activities[10]. Humic substances can be divided into three fractions; namely, humic acids (HAs) (soluble in an alkaline solution), fulvic acids (FAs) (fractionally soluble in an aqueous solution at any $\mathrm{pH}$ ), and humin (fractionally insoluble)[11]. Humic substances are known to be advantageous for soils to maintain aggregate stability and act as a potential source of nutrients for plants[12,13]. In addition, humic substances have been used in the formulation of organicbased fertilizer to reduce ammonia volatilization[14]. The reaction of humic substances with $\mathrm{N}$-containing compounds, such as urea, which is now widely used as a fertilizer, has considerable economic implications[15] to its slow release source.

Composting and its main attribute, i.e., humic substances, was the focus of this study. The objectives of the study were to: (1) produce organic K- and ammonium-based organic fertilizer from composted SW, and (2) determine the efficiency of the organic-based fertilizer produced.

\section{MATERIALS AND METHODS}

The SW was collected from Mukah, Sarawak, Malaysia. The SW was air dried and some of it was ground for the purpose of ashing, while ungrounded SW was used to produce compost.

Ground SW was incinerated at 300,350,400,450,500,550, and $600^{\circ} \mathrm{C}$ using a muffle furnace for $5 \mathrm{~h}$ in a beaker of $500 \mathrm{~mL}$. The best ash (almost white) was chosen for hydroxide production. The ash was dissolved in distilled water at ratios of 1:100, 1:200, 1:300, 1:400, and 1:500. The samples were equilibrated for $24 \mathrm{~h}$ at $150 \mathrm{rpm}$ using a mechanical shaker. Afterwards, the samples were filtered using Whatman filter paper number 2. The molarity was determined using acid-base titration. A ratio of 1:500 was chosen because its hydroxide had the highest molarity of $0.002 \mathrm{M}$ and $\mathrm{pH}$ of 10 . The chosen hydroxide was analyzed for its mineral content where it was found that $\mathrm{Ca}\left(42.88 \mathrm{mg} \mathrm{kg}^{-1}\right)$ and $\mathrm{K}(29.51$ $\mathrm{mg} \mathrm{kg}{ }^{-1}$ ) were high in the hydroxide compared to other elements. 
The composting process was done inside a white polystyrene box with a size of $61.5 \times 49 \times 33.5 \mathrm{~cm}$. The compost was produced by mixing SW $(80 \%)+$ chicken feed $(10 \%)+$ chicken dung slurry $(5 \%)+$ molasses $(5 \%)$. The ambient and compost temperatures were measured daily (morning and evening). The temperature of the compost was monitored until it equaled ambient temperature for 60 days, where it was considered mature. Turning was done once a week.

Humic acids were isolated by the method of Stevenson[16], but with some modifications. The compost and the hydroxide $(0.002 \mathrm{M})$ (extracted from the ash of SW) were placed inside a polyethylene bottle in a ratio of 1:10 (weight:volume basis). The mixture was shaken at $240 \mathrm{rpm}$ for $24 \mathrm{~h}$ at room temperature. Afterwards, the mixture was centrifuged for $15 \mathrm{~min}$ at $10,000 \mathrm{rpm}$. The dark-colored supernatant liquid containing HA was decanted, filtered using Whatman filter paper number 2, the $\mathrm{pH}$ of the liquid was adjusted to 1.0 using $6 \mathrm{~N} \mathrm{HCl}$, and it was allowed to stand at room temperature for $24 \mathrm{~h}$. The suspension containing HA was transferred into a polyethylene bottle and centrifuged at 10,000 rpm for $10 \mathrm{~min}$. The HA was purified by the method of Ahmed et al.[17], by using distilled water and through centrifugation at 10,000 rpm for $10 \mathrm{~min}$ to reduce mineral matter and $\mathrm{HCl}$ during acidification[18]. After the purification, the HA was oven dried at $40^{\circ} \mathrm{C}$ until constant weight was attained.

The soil of Bekenu series (Tipik Tualemkuts) was used for the pot experiment. Samples were taken at a depth of $0-30 \mathrm{~cm}$. Prior to planting, soil characteristics, such as texture, cation exchange capacity (CEC), exchangeable cations ( $\mathrm{K}, \mathrm{Ca}, \mathrm{Mg}, \mathrm{Na}$ ), organic matter, and organic carbon, were determined using the combustion method[19]; $\mathrm{pH}$ in water and $\mathrm{KCl}(1: 2.5 \mathrm{w}: \mathrm{v})$; available $\mathrm{P}$ using the blue method[20], total $\mathrm{N}$ using the Kjeldahl method[21], nitrate and ammonium content[22] were determined.

Production of the organic fertilizer was made through reconstitution of HA with hydroxide obtained from ashed SW $(0.002 \mathrm{M})$. The ratio thereof was set at 1:20, 1:40, 1:60, 1:80, and 1:100 (w:v). These mixtures were then shaken for $24 \mathrm{~h}$ at $150 \mathrm{rpm}$, after which they were analyzed for $\mathrm{K}, \mathrm{Ca}, \mathrm{Mg}$, and $\mathrm{Na}$ using AAS (atomic absorption spectrometry). Afterwards, the 1:40 mixture was found to yield the highest content of minerals $(\mathrm{K}, \mathrm{Ca}, \mathrm{Mg}, \mathrm{Na})$; thus, it was selected for fertilizer production. This liquid HA was designated as $\mathrm{T} 4$.

The compost and the hydroxide $(0.002 \mathrm{M})$ (extracted from the ash of $\mathrm{SW}$ ) were placed inside a polyethylene bottle at a ratio of 1:10 (w:v). The mixture was shaken at $240 \mathrm{rpm}$ for $24 \mathrm{~h}$ at room temperature. Later, it was centrifuged for $15 \mathrm{~min}$ at 10,000 rpm. The resulting dark liquid containing HAs and FAs was decanted. The mixtures were then used as treatments three (T3) and six (T6).

The humin (in solid form) deposits in the bottles were collected and analyzed for $\mathrm{pH}, \mathrm{CEC}$, exchangeable cation ( $\mathrm{K}, \mathrm{Ca}, \mathrm{Mg}, \mathrm{Na}$ ) (using leaching method), total $\mathrm{N}$ (using Kjeldahl method), and total minerals $(\mathrm{K}, \mathrm{Ca}, \mathrm{Mg}, \mathrm{Na}, \mathrm{Cu}, \mathrm{Zn}, \mathrm{Fe}, \mathrm{Mn}, \mathrm{P})$. All minerals were analyzed from the single dry ashing method[23]. All minerals except $\mathrm{P}$ were determined using AAS, while $\mathrm{P}$ was determined using color development (blue method) and analyzed using UV-vis spectrometer.

The pot experiment was conducted in a greenhouse at the Universiti Putra Malaysia Bintulu Sarawak Campus, using randomized complete block design (RCBD) with three replications. The pots used were in a size of $21.5 \times 28 \mathrm{~cm}$. The medium for each treatment consisted of $10 \mathrm{~kg}$ soil (based on bulk density of the soil), except for T4 and T5 where the soil had to be reduced to compensate for additional $200 \mathrm{~g}$ of humin for T5 and $100 \mathrm{~g}$ of humin for T6. The Masmadu variety of maize (Zea mays) was used as the test crop. Its fertilizer requirement was $60 \mathrm{~kg} \mathrm{~N}, 60 \mathrm{~kg} \mathrm{P}_{2} \mathrm{O}_{5}$, and $40 \mathrm{~kg} \mathrm{~K} 2 \mathrm{O}\left(130.44 \mathrm{~kg} \mathrm{ha}^{-1}\right.$ urea; $130.44 \mathrm{~kg}$ $\mathrm{ha}^{-1} \mathrm{TSP} ; 66.67 \mathrm{~kg} \mathrm{ha}^{-1} \mathrm{KCl}$ ). The fertilizer requirement was scaled down to per-pot basis equivalent to $4.85 \mathrm{~g}$ of urea, $4.85 \mathrm{~g}$ of TSP (triple superphosphate), and $2.5 \mathrm{~g}$ of $\mathrm{KCl}$. The volume of water for each pot was based on field capacity (50-60\%). The six treatments devised for this experiment were as follows:

T1: No fertilization

T2: NPK (4.85 g urea, $4.85 \mathrm{~g}$ TSP, $2.5 \mathrm{~g} \mathrm{KCl}$ ) (solid)

T3: $400 \mathrm{~mL}$ liquid of FA + HA mixed with $4.85 \mathrm{~g}$ of urea and $2.5 \mathrm{~g}$ of $\mathrm{KCl}+4.85 \mathrm{~g}$ TSP

T4: Liquid HA mixed with $4.85 \mathrm{~g}$ of urea and $2.5 \mathrm{~g}$ of $\mathrm{KCl}+4.85 \mathrm{~g}$ TSP

T5: $400 \mathrm{~mL} \mathrm{Ca-K}$ hydroxide (extracted from ash) mixed with $4.85 \mathrm{~g}$ of urea and $2.5 \mathrm{~g}$ of $\mathrm{KCl}+4.85$ $\mathrm{g}$ TSP $+200 \mathrm{~g}$ humin in soil 
T6: $400 \mathrm{~mL}$ liquid of FA + HA mixed with $4.85 \mathrm{~g}$ of urea and $2.5 \mathrm{~g}$ of $\mathrm{KCl}+4.85 \mathrm{~g}$ TSP $+100 \mathrm{~g}$ humin in soil

Treatments $\mathrm{T} 3$ to $\mathrm{T} 6$ were in liquid form where urea and $\mathrm{KCl}$ were added, shaken for $15 \mathrm{~min}$ at 150 rpm, and pH measured. TSP for T3, T4, T5, and T6 was applied separately by surface application. It is important to note that the 400-mL solution was chosen as Piccolo[24] recommended, that less than $1 \mathrm{~g}$ of HA per kilogram soil is adequate to condition soils. In this study, $10 \mathrm{~g}$ of HA was adulterated with 400 $\mathrm{mL}$ of hydroxide based on chosen ratio of 1:40, before being applied to $10 \mathrm{~kg}$ of soil. Hence, the volume of liquid fertilizer of all treatments was based on the volume of T4. All treatments were applied on the 10th day after sowing (DAS), but on the 28th DAS, only plants of T2 were fertilized. The plants were monitored and their heights were measured until the tassel stage. Tassel stage is the maximum growth stage for the plant before it goes to productive stage[14].

Harvesting was done on the 57th DAS. The whole plant, including leaves and stems, was harvested. The remaining roots in the soil were removed carefully and cleaned using tap and distilled water. The plant parts (leaves, stems, and roots) were then oven dried at $60^{\circ} \mathrm{C}$ until constant weight and their dry matter were determined. Soil samples were also taken from the pots and air dried, ground, and sieved to pass $2 \mathrm{~mm}$ before being analyzed for $\mathrm{pH}$, total carbon, total nitrogen, organic matter, $\mathrm{P}$, ammonium and nitrate, exchangeable cation $(\mathrm{K}, \mathrm{Ca}, \mathrm{Mg}, \mathrm{Na})$, and $\mathrm{CEC}$ using standard procedures. Each plant part was ground and analyzed for total $\mathrm{K}, \mathrm{Mg}, \mathrm{Ca}, \mathrm{Na}, \mathrm{N}$, and $\mathrm{P}$.

Nitrogen, $\mathrm{P}$, and K use efficiency were determined by the formula[25]:

$$
\% \text { Efficiency }=\frac{A-B}{C} \times 100
$$

where $\mathrm{A}=$ uptake with fertilizer, $\mathrm{B}=$ uptake without fertilizer, $\mathrm{C}=$ total amount of fertilizer that had been applied; uptake $=$ concentration $\times$ dry weight $(\mathrm{g})$.

Nitrogen, $\mathrm{P}$, and $\mathrm{K}$ uptake in leaves, stems, and roots were determined by multiplying the concentration with the dry weight of the plant parts. Analysis of variance (ANOVA) was used to test the effect of treatments, while means of treatments were compared using Tukey's Test. Statistical Analysis System (SAS Version 9.2) was used for the statistical analysis.

\section{RESULTS AND DISCUSSION}

The selected chemical and physical properties of Bekenu series (Tipik Tualemkuts) were relatively different from those reported by Paramanathan[26] (Table 1) because this soil has been cropped for some time.

The relatively high values of the selected chemical properties of the unpurified humin suggest the high quality of this humin fraction for plant growth and development (Table 2). For instance, neutral $\mathrm{pH}$, high organic matter, and CEC of the humin may have loosened the soil as well as improving nutrient retention when applied to soils. Besides serving as a source of nutrients, such as $\mathrm{N}, \mathrm{P}, \mathrm{K}, \mathrm{Ca}, \mathrm{Mg}$, and $\mathrm{Na}$, along with good $\mathrm{C} / \mathrm{N}$ ratio of the humin, it also ensures that immobilization will not occur when it is used in agriculture.

The $\mathrm{pH}$ of T3, T4, T5, and T6 did not change significantly before and after addition of urea and $\mathrm{KCl}$ (Table 3), suggesting that they were buffered.

The height of plants was monitored from 10 DAS until 57 DAS. Ten days after the first fertilization, the height of plants for T5 and T6 started to increase rapidly compared to other treatments. This was because the humin of T5 and T6 contributed to a slow release of nutrients in T5 and T6. Although both T3 and T6 had liquid HA and FA, the plants of T6 grew better than those of T3 due to the addition of humin to the soil of T6. The inclusion of humin might have loosened the soil, hence the better growth of the plants. Obviously, the plants of T1 were stunted, due to no fertilization. 
TABLE 1

Selected Physicochemical Characteristics of Bekenu Series

\begin{tabular}{lcc}
\hline Variables & Value Obtained & Standard Data Range[26] \\
\hline $\mathrm{pHw}$ & 6.45 & $4.6-4.9$ \\
$\mathrm{pHKCl}$ & 5.87 & $3.8-4.0$ \\
Exchangeable $\mathrm{K}\left(\mathrm{cmol} \mathrm{kg}^{-1}\right)$ & 0.13 & $0.05-0.19$ \\
Exchangeable $\mathrm{Na}\left(\mathrm{cmol} \mathrm{kg}^{-1}\right)$ & 0.06 & 0.01 \\
Exchangeable $\mathrm{Ca}\left(\mathrm{cmol} \mathrm{kg}^{-1}\right)$ & 10.10 & 0.01 \\
Exchangeable $\mathrm{Mg}\left(\mathrm{cmol} \mathrm{kg}^{-1}\right)$ & 0.26 & $0.07-0.21$ \\
$\mathrm{CEC}\left(\mathrm{cmol} \mathrm{kg}^{-1}\right)$ & 10.33 & $3.86-8.46$ \\
Total organic C $(\%)$ & 3.37 & $0.57-2.51$ \\
Organic matter $(\%)$ & 5.81 & $\mathrm{nd}$ \\
Total N $(\%)$ & 0.13 & $0.04-0.17$ \\
Available $\mathrm{P}\left(\mathrm{mg} \mathrm{kg}^{-1}\right)$ & 2.81 & $\mathrm{nd}$ \\
Ammonium $\left(\mathrm{mg} \mathrm{kg}^{-1}\right)$ & 25.69 & $\mathrm{nd}$ \\
Nitrate $\left(\mathrm{mg} \mathrm{kg}^{-1}\right)$ & 21.02 & $\mathrm{nd}$ \\
Bulk density $\left(\mathrm{g} \mathrm{cm}^{-3}\right)$ & 1.32 & $\mathrm{nd}$ \\
Clay $(\%)$ & 30 & $16-19$ \\
Sand $(\%)$ & 56 & $72-76$ \\
Silt (\%) & 14 & $8-9$ \\
\hline
\end{tabular}

TABLE 2

Selected Chemical Characteristics of Humin of Composted SW

\begin{tabular}{lc}
\hline Variables & Value \\
\hline $\mathrm{pH}$ & 7.16 \\
Total C (\%) & 28.68 \\
Organic matter (\%) & 49.45 \\
Total $\mathrm{N}(\%)$ & 2.16 \\
Total $\mathrm{P}\left(\mathrm{mg} \mathrm{kg}^{-1}\right)$ & 6076.05 \\
Total K $\left(\mathrm{mg} \mathrm{kg}^{-1}\right)$ & 6380.80 \\
$\mathrm{CEC}\left(\mathrm{cmol} \mathrm{kg}^{-1}\right)$ & 142 \\
Exchangeable $\mathrm{Ca}\left(\mathrm{cmol} \mathrm{kg}^{-1}\right)$ & 55.23 \\
Exchangeable $\mathrm{Mg}\left(\mathrm{cmol} \mathrm{kg}^{-1}\right)$ & 24.28 \\
Exchangeable $\mathrm{K}\left(\mathrm{cmol} \mathrm{kg}^{-1}\right)$ & 65.79 \\
Exchangeable $\mathrm{Na}\left(\mathrm{cmol} \mathrm{kg}^{-1}\right)$ & 33.36 \\
\hline
\end{tabular}

Dry weight of leaf, stem, and root for T5 and T6 was significantly higher than that of T1, T2, T3, and T4. This observation was partly because of humin in T5 and T6 (Table 4).

Observation shows that the relative absorption rates of $\mathrm{N}$ and $\mathrm{P}$ in maize occurs after 28 days of cultivation, while that of $\mathrm{K}$ reaches maximum rate during the early days of planting[27]; hence, the rapid growth of plants of T5 and T6. 
TABLE 3

$\mathrm{pH}$ Values of Treatments Before and After Fertilizer Formulation

\begin{tabular}{lccc}
\hline \multirow{2}{*}{ Label } & Treatment & \multicolumn{2}{c}{$\mathbf{p H}$} \\
\cline { 3 - 4 } & & Without Urea + KCl & With Urea + KCl \\
\hline T3 & (Lquid HA + FA) + NK & 7.46 & 7.43 \\
T4 & Recons. HA + NK & 2.33 & 2.46 \\
T5 & Hydroxide + NK & 10 & 10.66 \\
T6 & (Liquid HA + FA) + NK & 7.47 & 7.46 \\
\hline
\end{tabular}

TABLE 4

Dry Weight of Leaves, Stems, and Roots of Maize Plants at 57 DAS

\begin{tabular}{lcccc}
\hline \multirow{2}{*}{ Treatment } & \multicolumn{4}{c}{ Dry Weight of Plant $\left(\right.$ g plant $\left.^{-1}\right)$} \\
\cline { 2 - 5 } & Leaves & Stems & Roots & Total \\
\hline T1 & $2.83 \mathrm{a}$ & $1.28 \mathrm{a}$ & $1.09 \mathrm{a}$ & $5.20 \mathrm{a}$ \\
T2 & $1.77 \mathrm{a}$ & $0.71 \mathrm{a}$ & $0.40 \mathrm{a}$ & $2.87 \mathrm{a}$ \\
T3 & $2.60 \mathrm{a}$ & $1.30 \mathrm{a}$ & $0.97 \mathrm{a}$ & $4.87 \mathrm{a}$ \\
T4 & $2.26 \mathrm{a}$ & $1.01 \mathrm{a}$ & $1.05 \mathrm{a}$ & $4.32 \mathrm{a}$ \\
T5 & $15.49 \mathrm{~b}$ & $22.58 \mathrm{~b}$ & $6.34 \mathrm{~b}$ & $44.41 \mathrm{~b}$ \\
T6 & $12.59 \mathrm{~b}$ & $17.57 \mathrm{~b}$ & $5.40 \mathrm{~b}$ & $35.55 \mathrm{~b}$ \\
\hline
\end{tabular}

Different letters within a column indicate significant difference between means using Tukey's test at $p=0.05$.

Except for $\mathrm{P}$, the contents of $\mathrm{N}$ and $\mathrm{K}$ in leaves and roots were not significant regardless of treatment (Table 5), and this observation could be due to the dilution effect[28]. The $\mathrm{P}$ concentration of these parts was significantly higher for T5 and T6 compared to T1. With the exception of P, the contents of $\mathrm{N}$ and $\mathrm{K}$ of stems for T5 and T6 (treatments with better dry matter production) were not significantly different from T1. This was possible because at critical concentration, growth does not increase to balance the additional nutrient uptake[29].

Treatments with humin (T5 and T6) consistently had significant effect on N, P, and K uptake in leaves, stems, and roots (Table 6) compared to other treatments. A similar observation was made for N, P (except for root), and K use efficiency in leaves, stems, and roots (Table 7). The addition of humin (T5 and T6) possibly acted as a bulky material that enhanced the ability of the soil to resist applied load[30] and increased the porosity of the soil; hence, causing improvement of air and water movement[31]. Compost was found to have a positive effect on crops only when applied with additional N-fertilizer[32], and this was consistent with the findings that T5 and T6 caused better plant growth with half the usual amount of fertilizer (e.g., T2, two times fertilization). Additionally, only 1\% of HA was extracted from the composted SW due to mild hydroxide $(0.002 \mathrm{M})$ used for the extraction. Hence, it was considered that humin was still high in HA and FA.

Furthermore, although the fertilization of plants under T5 and T6 was once, total N, P, and K from humin plus inorganic fertilizer provided additional nutrients for the plants. The addition of inorganic fertilizer into compost is a combination of quick and slow release sources, which supplies $\mathrm{N}$ throughout the crop growth period. Besides, observation shows that, $\mathrm{N}, \mathrm{K}$, and $\mathrm{Mg}$ concentrations were high in the soil due to mineralization of humin in the soil[33]. 
TABLE 5

Effect of Different Treatments on Contents of $\mathrm{N}, \mathrm{P}$, and $\mathrm{K}$ in Leaves, Stems, and Roots of Maize Plants at 57 DAS

\begin{tabular}{lccc}
\hline & $\mathbf{N}$ & $\mathbf{P}$ & $\mathbf{K}$ \\
\cline { 2 - 4 } Treatment & & $\mathbf{( \% )}$ & \\
\cline { 2 - 4 } Leaves & & & \\
T1 & $2.695 \mathrm{a}$ & $0.076 \mathrm{~b}$ & $0.916 \mathrm{a}$ \\
T2 & $2.984 \mathrm{a}$ & $0.065 \mathrm{~b}$ & $1.689 \mathrm{a}$ \\
T3 & $3.034 \mathrm{a}$ & $0.094 \mathrm{~b}$ & $1.890 \mathrm{a}$ \\
T4 & $3.116 \mathrm{a}$ & $0.083 \mathrm{~b}$ & $1.063 \mathrm{a}$ \\
T5 & $3.060 \mathrm{a}$ & $0.192 \mathrm{a}$ & $0.709 \mathrm{a}$ \\
T6 & $3.105 \mathrm{a}$ & $0.157 \mathrm{a}$ & $0.775 \mathrm{a}$ \\
Stems & & & \\
T1 & $2.797 \mathrm{bc}$ & $0.071 \mathrm{c}$ & $2.553 \mathrm{c}$ \\
T2 & $4.007 \mathrm{a}$ & $0.083 \mathrm{bc}$ & $3.682 \mathrm{~b}$ \\
T3 & $3.960 \mathrm{a}$ & $0.125 \mathrm{a}$ & $4.626 \mathrm{a}$ \\
T4 & $3.534 \mathrm{ab}$ & $0.101 \mathrm{abc}$ & $4.413 \mathrm{ab}$ \\
T5 & $1.956 \mathrm{c}$ & $0.138 \mathrm{a}$ & $1.742 \mathrm{c}$ \\
T6 & $2.399 \mathrm{c}$ & $0.124 \mathrm{ab}$ & $1.856 \mathrm{c}$ \\
Roots & & & \\
T1 & & & \\
T2 & $1.845 \mathrm{a}$ & $0.059 \mathrm{c}$ & $1.815 \mathrm{a}$ \\
T3 & $2.182 \mathrm{a}$ & $0.089 \mathrm{bc}$ & $2.367 \mathrm{a}$ \\
T4 & $2.285 \mathrm{a}$ & $0.075 \mathrm{abc}$ & $2.458 \mathrm{a}$ \\
T5 & $1.837 \mathrm{a}$ & $0.106 \mathrm{a}$ & $2.195 \mathrm{a}$ \\
T6 & $1.912 \mathrm{a}$ & $0.103 \mathrm{ab}$ & $2.715 \mathrm{a}$ \\
\hline
\end{tabular}

Different letters within a column indicate significant difference between means using Tukey's test at $p=0.05$.

Liquid HA and FA with the addition of humin (T6) in the soil had a remarkable effect on total dry weight (Table 4) and efficiency (Table 7) compared to T3 because FAs have high affinity for mineral chelating and plant growth. They can readily enter plant roots, stems, and leaves, and because of their high exchange capacity as they enter into plant parts, they could carry trace minerals into plant tissues[34]. FAs in acidic condition have the ability to retain $\mathrm{NH}_{4}{ }^{+}$ions from urea during hydrolysis[14]. FAs present in low concentration in humic substances have higher acidity than HAs, and thus they are likely to affect stronger soil CEC than HAs[35].

The addition of urea in liquid HA was expected to increase the $\mathrm{pH}$ of HA solution, but the result was not as expected. This was because HAs tend to be more aromatic and more prone to precipitation under acidic conditions common in many soils, making them less mobile[36].

Common fertilization by surface application of $\mathrm{T} 2$ without any additives (acidic and high CEC materials) can cause nutrients to be easily lost, especially $\mathrm{N}$ and $\mathrm{K}$, through volatilization and leaching, but based on the soil characteristics, the soil treated with $\mathrm{T} 2$ had quite a high content of $\mathrm{N}$ and ammonium compared with other treatments (Table 8). The poor nutrient use efficiency observed for T2 was partly because of poor root development (Table 4). Besides, high $\mathrm{Ca}$ in the soil (Table 1) may have reacted with phosphate from the fertilizer to form $\mathrm{Ca}$ phosphate, an insoluble compound of phosphate that is generally not available to plants, especially roots. Phosphorus is very important for root development. Stunted roots may affect the whole growth system of a plant negatively. This might be one of the reasons for the poor plant growth, nutrient uptake, and use efficiency observed for plants of T2, T3, and T4. 
TABLE 6

Effect of Different Treatments on Uptake of $N, P$, and $K$ in Leaves, Stems, and Roots of Maize Plants at 57 DAS

\begin{tabular}{|c|c|c|c|}
\hline \multirow{2}{*}{ Treatment } & $\mathbf{N}$ & $\mathbf{P}$ & $\mathbf{K}$ \\
\hline & \multicolumn{3}{|c|}{ (mg plant $^{-1}$ ) } \\
\hline \multicolumn{4}{|l|}{ Leaves } \\
\hline $\begin{array}{l}\text { T1 } \\
\text { T2 } \\
\text { T3 } \\
\text { T4 } \\
\text { T5 } \\
\text { T6 }\end{array}$ & $\begin{array}{c}77.159 b \\
52.783 b \\
78.727 b \\
69.647 b \\
473.186 a \\
397.392 a\end{array}$ & $\begin{array}{c}2.232 b \\
0.865 b \\
2.411 b \\
1.926 b \\
29.794 a \\
20.160 a\end{array}$ & $\begin{array}{c}24.633 c \\
30.199 c \\
47.042 b c \\
24.325 c \\
109.076 a \\
95.613 a b\end{array}$ \\
\hline \multicolumn{4}{|l|}{ Stems } \\
\hline $\begin{array}{l}\text { T1 } \\
\text { T2 } \\
\text { T3 } \\
\text { T4 } \\
\text { T5 } \\
\text { T6 }\end{array}$ & $\begin{array}{c}37.010 \mathrm{~b} \\
28.712 \mathrm{~b} \\
50.460 \mathrm{~b} \\
44.458 \mathrm{~b} \\
432.334 \mathrm{a} \\
418.864 \mathrm{a}\end{array}$ & $\begin{array}{c}0.918 b \\
0.555 b \\
1.583 b \\
1.020 b \\
31.376 a \\
21.815 a\end{array}$ & $\begin{array}{c}32.471 b \\
26.312 b \\
59.175 b \\
44.212 b \\
377.954 a \\
322.223 a\end{array}$ \\
\hline \multicolumn{4}{|l|}{ Roots } \\
\hline $\begin{array}{l}\text { T1 } \\
\text { T2 } \\
\text { T3 } \\
\text { T4 } \\
\text { T5 } \\
\text { T6 }\end{array}$ & $\begin{array}{c}20.786 b c \\
8.012 \mathrm{c} \\
20.338 \mathrm{bc} \\
23.920 \mathrm{bc} \\
121.404 \mathrm{a} \\
105.894 \mathrm{a}\end{array}$ & $\begin{array}{l}0.608 b \\
0.272 b \\
0.881 b \\
0.781 b \\
6.838 a \\
5.653 a\end{array}$ & $\begin{array}{c}19.891 b c \\
9.474 c \\
23.522 b c \\
26.430 b c \\
136.161 a \\
152.599 a\end{array}$ \\
\hline
\end{tabular}

Among the selected chemical properties analyzed at 57 DAS (Table 8), soil available P was significantly affected by T5 and T6 compared to other treatments. The better growth and development of the maize plants subjected to these two treatments was consistent with this observation. Phosphorus is noted for facilitating good plant root systems, which in turn leads to overall plant growth and development.

\section{CONCLUSION}

Mixing soil with humin produced from composted SW before application of fertilizers (T5 and T6) significantly increased maize dry matter production, N, P, and K uptake. This practice does not only improve N, P, and K use efficiency, but it also helps to reduce the use of N-, P-, and K-based fertilizers by $50 \%$.

\section{ACKNOWLEDGMENTS}

This study was supported by a Fund from the Ministry of Agriculture and Agro-based Industry Malaysia entitled "Utilization of Sago Waste in Animal Production". The authors acknowledge the assistance of the staff of the Universiti Putra Malaysia, Bintulu Sarawak Campus. 
TABLE 7

Effect of Different Treatments on N, P, and K Use Efficiency in Leaves, Stems, and Roots of Maize Plant at 57 DAS

\begin{tabular}{|c|c|c|c|c|}
\hline Treatment & Leaves & Stems & Roots & Total \\
\hline & \multicolumn{4}{|c|}{$\% \mathbf{N}$} \\
\hline $\mathrm{T} 1$ & $\mathrm{Nd}$ & $\mathrm{Nd}$ & $\mathrm{Nd}$ & $\mathrm{Nd}$ \\
\hline T2 & $1.574 b$ & $0.682 b$ & $0.708 \mathrm{~b}$ & 2.957 \\
\hline T3 & $0.888 \mathrm{~b}$ & $0.675 b$ & $0.500 \mathrm{~b}$ & 2.064 \\
\hline T4 & $0.357 \mathrm{~b}$ & $0.491 b$ & $0.466 \mathrm{~b}$ & 1.314 \\
\hline T5 & $17.751 a$ & $17.720 a$ & $4.510 \mathrm{a}$ & 39.981 \\
\hline \multirow[t]{2}{*}{ T6 } & $14.354 a$ & 17.116a & $3.815 a$ & 35.283 \\
\hline & \multicolumn{4}{|c|}{$\% \mathbf{P}$} \\
\hline $\mathrm{T} 1$ & $\mathrm{Nd}$ & $\mathrm{Nd}$ & $\mathrm{Nd}$ & $\mathrm{Nd}$ \\
\hline T2 & $0.061 b$ & $0.021 b$ & $0.018 a$ & 0.099 \\
\hline T3 & $0.054 b$ & $0.030 \mathrm{~b}$ & $0.009 a$ & 0.093 \\
\hline T4 & $0.034 b$ & $0.005 b$ & $0.001 a$ & 0.039 \\
\hline T5 & $1.235 \mathrm{a}$ & $1.365 \mathrm{a}$ & $0.007 a$ & 2.607 \\
\hline \multirow[t]{2}{*}{ T6 } & $0.804 a$ & $0.937 a$ & $0.006 a$ & 1.746 \\
\hline & \multicolumn{4}{|c|}{$\% \mathrm{~K}$} \\
\hline $\mathrm{T} 1$ & $\mathrm{Nd}$ & $\mathrm{Nd}$ & $\mathrm{Nd}$ & $\mathrm{Nd}$ \\
\hline T2 & $1.759 \mathrm{bc}$ & $0.931 b$ & $0.904 b$ & 3.594 \\
\hline T3 & $1.624 b c$ & $1.780 \mathrm{~b}$ & $0.441 b$ & 3.846 \\
\hline T4 & $0.474 \mathrm{c}$ & $0.783 b$ & $0.908 \mathrm{~b}$ & 2.163 \\
\hline T5 & $5.630 \mathrm{a}$ & $23.032 a$ & $7.751 a$ & 36.414 \\
\hline T6 & $3.871 a b$ & $19.317 a$ & $8.777 a$ & 31.965 \\
\hline
\end{tabular}

Different letters within a column indicate significant difference between means using Tukey's test at $p=0.05$. Nd, not determined.

TABLE 8

Soil Selected Chemical Characteristics at 57 DAS

\begin{tabular}{|c|c|c|c|c|c|c|c|}
\hline & Initial & T1 & T2 & T3 & T4 & T5 & T6 \\
\hline $\mathrm{pHKCl}$ & $5.87 a b c$ & $5.84 \mathrm{abc}$ & $5.74 \mathrm{bc}$ & $5.64 b c$ & $5.53 c$ & $6.33 a$ & $6.17 a b$ \\
\hline $\mathrm{pHw}$ & $6.45 a b$ & $6.10 \mathrm{bcd}$ & $5.99 \mathrm{~cd}$ & $5.93 \mathrm{~cd}$ & $5.76 \mathrm{~d}$ & $6.56 a$ & $6.27 a b c$ \\
\hline Exchangeable $\mathrm{K}\left(\mathrm{cmol} \mathrm{kg}^{-1}\right)$ & $0.132 \mathrm{c}$ & $0.129 c$ & $1.458 \mathrm{a}$ & $1.118 a b$ & $1.048 \mathrm{abc}$ & $0.435 \mathrm{cb}$ & $0.499 \mathrm{cb}$ \\
\hline Exchangeable $\mathrm{Na}\left(\mathrm{cmol} \mathrm{kg}^{-1}\right)$ & $0.056 \mathrm{~d}$ & $0.096 \mathrm{~cd}$ & $0.174 \mathrm{bcd}$ & $0.272 b c$ & $0.160 \mathrm{bcd}$ & $0.553 a$ & $0.329 b$ \\
\hline Exchangeable $\mathrm{Ca}\left(\mathrm{cmol} \mathrm{kg}^{-1}\right)$ & $10.104 a$ & $7.376 a$ & $7.142 \mathrm{a}$ & $10.326 a$ & $8.970 a$ & $11.907 \mathrm{a}$ & $10.337 a$ \\
\hline Exchangeable $\mathrm{Mg}\left(\mathrm{cmol} \mathrm{kg}^{-1}\right)$ & $0.264 d$ & $0.463 \mathrm{bcd}$ & $0.396 \mathrm{~cd}$ & $0.642 a b c$ & $0.547 \mathrm{bcd}$ & $0.888 a$ & $0.723 a b$ \\
\hline $\operatorname{CEC}\left(\mathrm{cmol} \mathrm{kg}^{-1}\right)$ & $10.330 \mathrm{~b}$ & $22.222 a$ & $20.333 a$ & $22.000 \mathrm{a}$ & $31.056 a$ & $29.778 a$ & $34.833 a$ \\
\hline Total C (\%) & $3.368 a b$ & $3.112 b$ & $3.176 b$ & $3.436 \mathrm{ab}$ & $3.131 b$ & $3.694 a$ & $3.371 \mathrm{ab}$ \\
\hline Organic matter (\%) & $5.806 a b$ & $5.366 b$ & $5.476 \mathrm{~b}$ & $5.925 a b$ & $5.398 b$ & $6.368 a$ & $5.812 a b$ \\
\hline Total N (\%) & $0.126 a$ & $0.171 \mathrm{a}$ & $0.188 a$ & $0.133 a$ & $0.083 a$ & $0.072 \mathrm{a}$ & $0.059 a$ \\
\hline Available $\mathrm{P}\left(\mathrm{mg} \mathrm{kg}^{-1}\right)$ & $2.807 \mathrm{c}$ & $2.113 \mathrm{c}$ & $2.239 \mathrm{c}$ & $2.688 \mathrm{c}$ & $2.693 \mathrm{c}$ & $13.126 \mathrm{a}$ & $6.854 b$ \\
\hline Ammonium $\left(\mathrm{mg} \mathrm{kg}^{-1}\right)$ & $25.685 c$ & $48.257 b$ & $96.124 a$ & $44.365 \mathrm{bc}$ & $56.040 \mathrm{~b}$ & $45.143 b c$ & $49.813 b$ \\
\hline Nitrate $\left(\mathrm{mg} \mathrm{kg}^{-1}\right)$ & $21.015 b$ & $36.582 a$ & $45.922 a$ & $41.641 \mathrm{a}$ & $45.143 a$ & $36.582 a$ & $43.587 a$ \\
\hline
\end{tabular}

Different letters within a column indicate significant difference between means using Tukey's test at $p=0.05$. 


\section{REFERENCES}

1. Apun, K., Lihan, S., Wong, M.K., and Bilung, L.M. (2009) Microbiological Characteristics of Trunking and NonTrunking Sago Palm Peat Soil. Programme and Abstract. 1st ASEAN Sago Symposium 2009. Current Trend and Development in Sago Research. October 29-30, 2009. Riverside Majestic Hotel, Kuching, Sarawak, Malaysia.

2. Cecil, J. (2002) The development of technology for the extraction of sago. In New Frontiers of Sago Palm Studies. Proceedings of the International Symposium on SAGO (SAGO 2001). Kainuma, K., Okazaki, M., Toyoda, Y., and Cecil, J.E., Eds. Universal Academy Press, Tokyo. pp: 83-91.

3. Oates, C. and Hicks, A. (2002) Sago starch production in Asia and the Pacific--problems and prospects. In New Frontiers of Sago Palm Studies. Proceedings of the International Symposium on SAGO (SAGO 2001). Kainuma, K., Okazaki, M., Toyoda, Y., and Cecil, J.E., Eds. Universal Academy Press, Tokyo. pp: 27-36

4. Vikineswary, S., Shim, Y.L, Thambirajah, J.J., and Blakebrough, N. (1994) Possible microbial utilization of sago processing wastes. Resour. Conserv. Recy. 11, 289-296.

5. Haska, N. (2002) The utilization of the fibrous residue of sago palm as a substrate for the cultivation of edible mushrooms. In New Frontiers of Sago Palm Studies. Proceedings of the International Symposium on SAGO (SAGO 2001). Kainuma, K., Okazaki, M., Toyoda, Y., and Cecil, J.E., Eds. Universal Academy Press, Tokyo. pp: $133-140$.

6. Singhal, R.S., Kennedy, J.F., Sajilata, M.G., Kaczmarek, A., Knill, C.J., and Akmar, P.F. (2007) Industrial production, processing, and utilization of sago palm-derived products. Carbohydr. Polym. 72, 1-20

7. Quek, S.Y., Wase, D.A.J., and Forster, C.F. (1998) The use of sago waste for the sorption of lead and copper. Water S. A. 24, 251-256.

8. Smidt, E., Meissl, K., Schmutzer, M., and Hinterstoisser, B. (2007) Co-composting of lignin to build of humic substances- Strategies in waste management to improve compost quality. Ind. Crops Prod. 27, 196-201.

9. Campitelli, P.A., Velasco, M.I., and Ceppi, S.B. (2006) Chemical and physicochemical characteristics of humic acids extracted from compost, soil and amended soil. Talanta 69, 1234-1239.

10. Pena-Mendez E.M., Havel, J., and Patocka, J. (2005) Humic substances-compounds of still unknown structure: applications in agriculture, industry, environment, and biomedicine. J. Appl. Biomed. 3, 13-24.

11. Chilom, G., Bruns, A.S., and Rice, J.A. (2009) Aggregation of humic acid in solution: contributions of different fractions. Org. Geochem. 40, 455-460.

12. Lulakis, M.D. and Petsas, S.I. (1995) Effect of humic substances from vine-canes mature compost on tomato seedling growth. Bioresour. Technol. 54, 179-182.

13. Zbytniewski, R. and Buszewski, B. (2005) Characterization of natural organic matter (NOM) derived from sewage sludge compost. Part 1: chemical and spectroscopic properties. Bioresour. Technol. 96, 471-478.

14. Susilawati, K., Ahmed, O.H., Nik Muhammad, A.B., Khanif, M.Y., and Jalloh, M.B. (2009) Effect of organic based $\mathrm{N}$ fertilizer on dry matter (Zea mays L.), ammonium and nitrate recovery in an acid soil of Sarawak, Malaysia. Am. J. Appl. Sci. 6(7), 1282-1287.

15. Helal, A.A., Imam, D.M., Khalifa, S.M., and Aly, H.F. (1998) Effect of some environmental ligands and fertilizers on humic acid complexation with strontium. J. Radioanal. Nucl. Chem. 232, 159-161.

16. Stevenson, F.J. (1994) Humus Chemistry: Genesis, Composition, Reactions. 2nd ed. John Wiley \& Sons, New York. p. 36.

17. Ahmed, O.H., Husni, M.H.A., Anuar, A.R., Hanafi, M.M., and Angela, E.D.S. (2004) A modified way of producing humic acid from pineapple leaves. J. Sustain. Agric. 25(1), 129-139.

18. Susilawati, K., Ahmed, O.H., Nik Muhamad, A.M., and Khanif, M.Y. (2008) Simple method of purifying humic acids isolated from tropical hemists (peat soil). Am. J. Appl. Sci. 5(12), 1812-1815.

19. Chefetz, B., Hatcher, P.H., Hadar, Y., and Chen, Y. (1996) Chemical and biological characterization of organic matter during composting of municipal solid waste. J. Environ. Qual. 25, 776-785.

20. Murphy, J. and Riley, J.I. (1962) A modified single solution method for the determination of phosphate in natural waters. Anal. Chim. Acta 27, 31-36.

21. Bremner, J.M. (1965) Total nitrogen. Am. Soc. Agron. Monogr. 9, 1149-1178.

22. Keeney, D.R. and D.W. Nelson (1982) Nitrogen--inorganic forms. In Methods of Soil Analysis, Part 2. 2nd ed. Page, A.L., Keeney, D.R., Baker, D.E., Miller, R.H., Ellis, R., Jr., and Rhoades, J.D., Eds. Agron. Monogr. 9. ASA and SSSA, Madison, WI.

23. Cottenie, A. (1980) Soil testing and plant testing as a basis of fertilizer reccomendation. FAO Soils Bull. 38, 70-73.

24. Piccolo, A. (1996) Humus and soil conservation. Humic Substances in Terrestrial Ecosystems. Piccolo, A., Ed. Elsevier, Amsterdam. pp. 225-264.

25. Pomares-Garcia, F. and Pratt, P.F. (1987) Recovery of $15 \mathrm{~N}$-labelled fertilizer from manured and sludgedamended soils. Soil Sci. Soc. Am. J. 42, 717-720.

26. Paramananthan, S. (2000) Soils of Malaysia: Their Characteristics and Identification. Vol. 1. Academy of Sciences Malaysia, Kuala Lumpur.

27. Minar, J. and Laztuvka, Z. (1969) The dynamics of the accumulation of nitrogen, phosphorus and potassium in maize and peas in the first growth phases at constant mineral nutrition. Biol. Plantarum 11(2), 149-157.

28. Mengel, K. and Kirby, E.A. (1996) Principles of Plant Nutrition. 4th ed. Panina Publishing, New Delhi. pp. $147-149$. 
29. Singer, M.J. and Munns, D.N. (2006) Soils: An Inroduction. Pearson - Prentice Hall, Upper Saddle River, NJ.

30. Soane, B.D. (1990) The role of organic matter in soil compactibility: a review of some practical aspects. Soil Tillage Res. 16, 179-201.

31. Koivula, N., Hanninen, K., and Tolvanen, O. (2000) Windrow composting of source separated kitchen biowastes in Finland. Waste Manage. Res. 18, 160-173.

32. Bar-Tal, A., Yermiyahu, U., Beraud, J., Keinan, M., Rosenber, R., Zohar, D., Rosen, V., and Fine. P. (2004)

Nitrogen, phosphorus, potassium uptake by wheat and their distribution in soil following succesive, annual compost applications. J. Environ. Qual. 33, 1855-1865.

33. Mylavarapu, R.S. and Zinati, G.M. (2009) Improvement of soil properties using compost for optimum parsley production in sandy soils. Sci. Hortic. 120, 426-430.

34. Amir, S., Hafidi, M., Merlina, G., and Revel, J.-C. (2005) Structural characterization of fulvic acids during composting of sewage sludge. Process Biochem. 40, 1693-1700.

35. Adani, F., Genevini, P., Tambone, F., and Montoneri, E. (2006) Compost effect on doil humic acid: a NMR study. Chemosphere 65, 1414-1418.

36. Rivero, C., Chirenje, T., Ma, L.Q., and Martinez, G. (2004) Influence of compost on soil organic matter quality under tropical conditions. Geoderma 123, 355-361.

\section{This article should be cited as follows:}

Petrus, A.C., Ahmed, O.H., Muhamad, A.M.N., Nasir, H.M., and Jiwan, M. (2010) Effect of K-N-humates on dry matter production and nutrient use efficiency of maize in Sarawak, Malaysia. TheScientificWorldJOURNAL: TSW Environment 10, 1282-1292. DOI 10.1100/tsw.2010.121. 


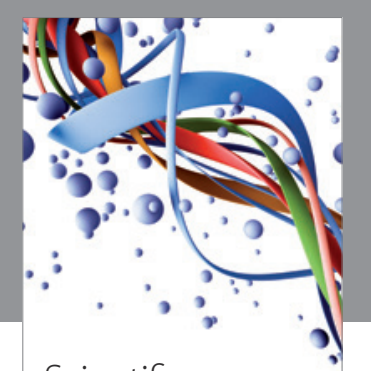

Scientifica
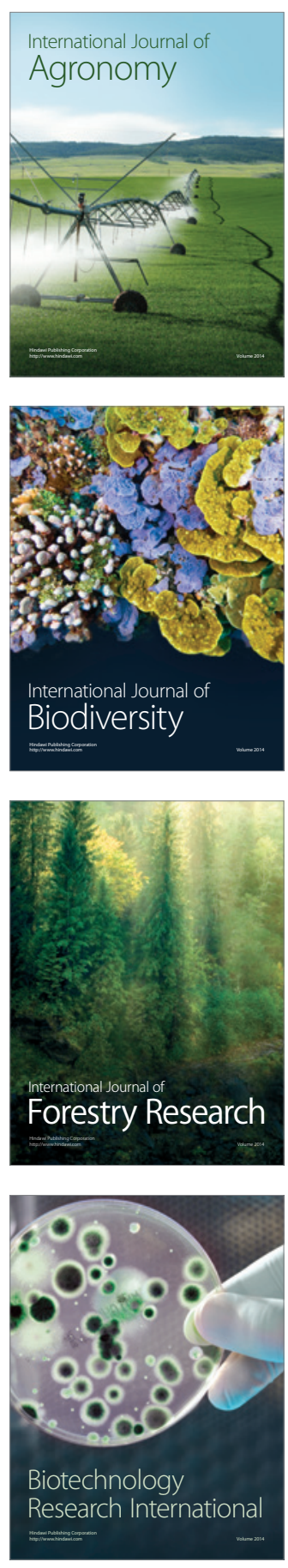
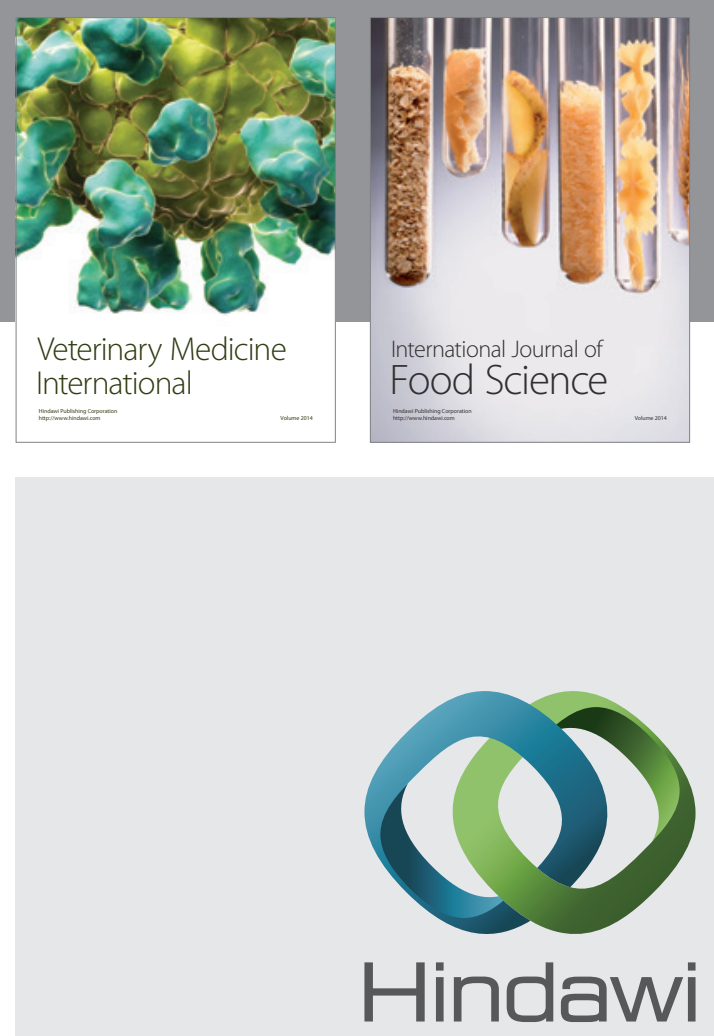

Submit your manuscripts at

http://www.hindawi.com
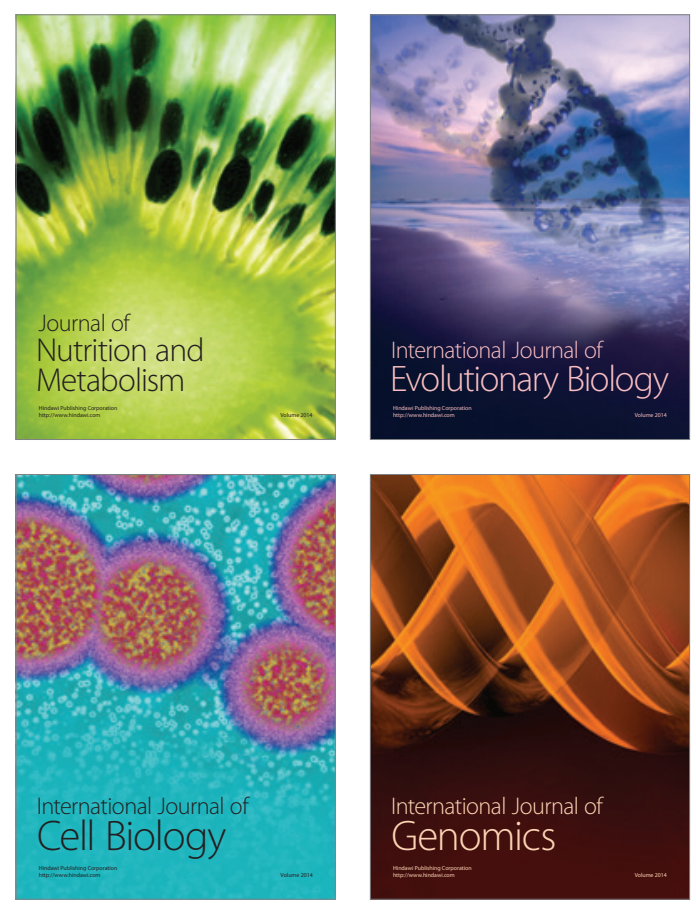
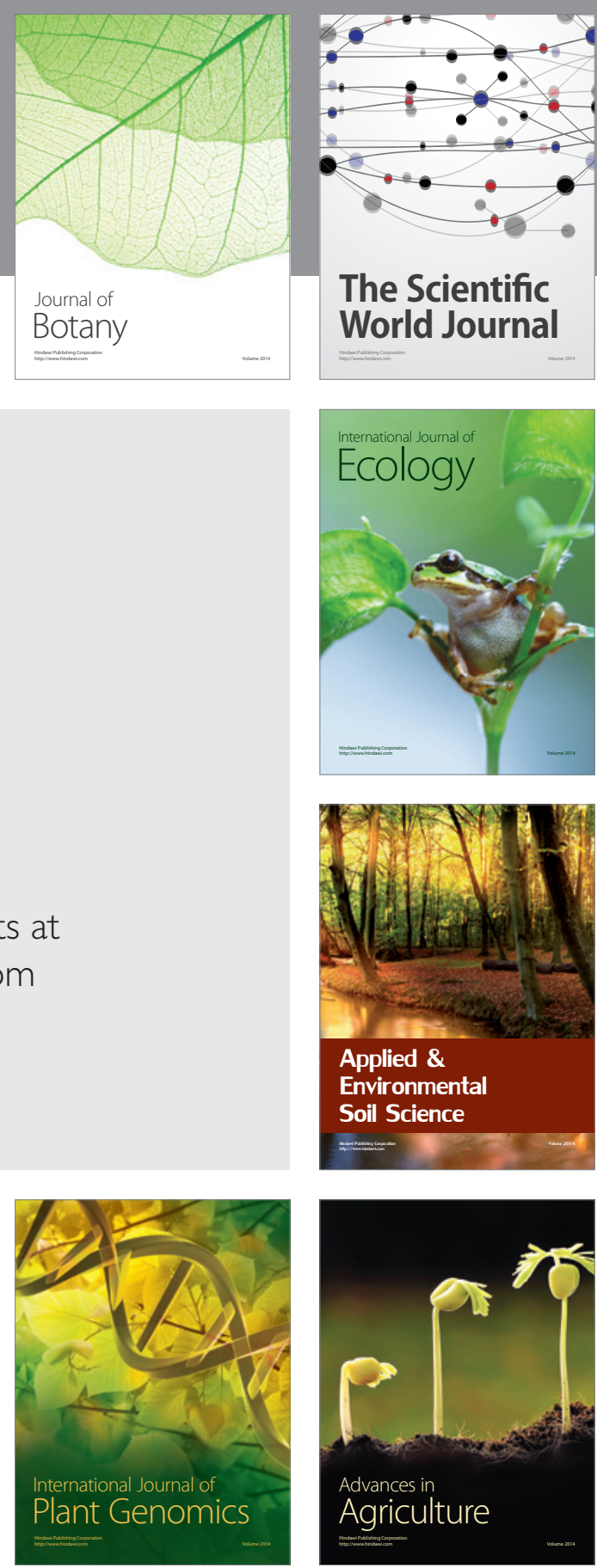

The Scientific World Journal
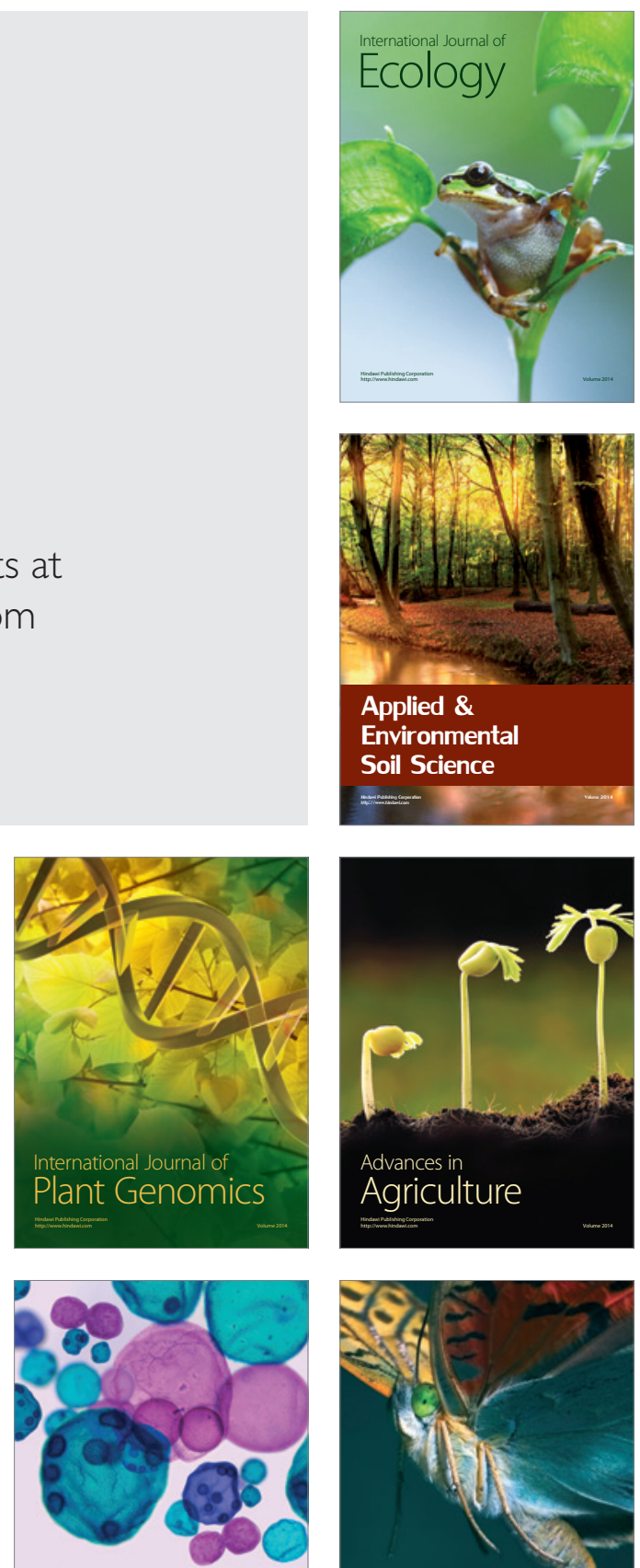

International Journal of Microbiology

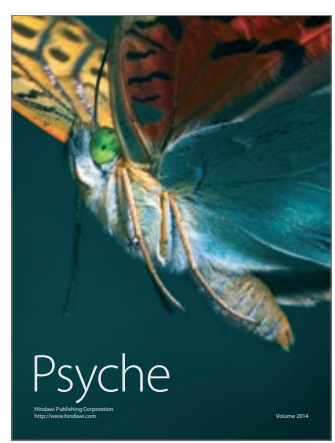

